\title{
THE GENESIS AND THE DEVELOPMENT \\ OF THE ENGLISH-LANGUAGE CHILDREN'S POETRY
}

\section{Pikalova Anna ${ }^{1}$}

DOI: dx.doi.org/10.30525/978-9934-571-30-5_15

Abstract. In the culture of each country, children's literature has its own history and specifics. However, children's literature in different countries has common features. Children's literature includes works of fiction that are directly addressed to children and specially created for them. The aim of the research is to identify the main features of the stages of development of English-language children's poetry. The object of the study is the process of genesis and development of the English-language children's poetry. From the birth up to now, poetry for children is formed by the generations of children and the literature of childhood in general. Each new generation of children led to the emergence of new poetic texts for the young reader, which corresponded to the historical, cultural, social and other conditions of the development of a certain country. Oral folk art can be defined as a tendency for the preparatory process of formation of children's literature with its genre diversity in a separate direction in the cultural-historical process of the formation of literature in general. The emergence of printing is the beginning of the genesis of children's literature. The collection of folk tales "Tales of Mother Goose" was published in English. The morals to them were written in rhymed form. A significant contribution to the development of children's poetry is the publication of John Newbery's book " $A$ Little Pretty Pocket-Book" (1744). This book was important both in the didactic and entertainment aspects. In 1846, the world saw the book of Edward Lear "Book of Nonsense". This book has begun a new stage in the development of English-language children's poetry. Humour is the main feature of children's poetry in the twentieth century. One of the most popular children's poets of that time is Theodore Seuss Geisel / Dr. Seuss. His collection "The Cat in the Hat" (1957) is a contribution to the development of the genre, which has gradually become popular. At the end of the twentieth century,

\footnotetext{
${ }^{1}$ Ph.D. in Linguistics, Associate Professor at Foreign Philology Department, Municipal Establishment "Kharkiv Humanitarian and Pedagogical Academy" Kharkiv Regional Council, Ukraine

(C) Pikalova Anna
} 
children's poetry is supplemented with such names as Sheldon Alan 'Shel' Silverstein and Jack Prelutsky. The development of children's poetry is accompanied by the improvement of its visual design. XXI century brings to our lives new social changes and the constant development of electronic technologies. Rapid technical progress makes it possible to create new resources for familiarizing children with the world of poetry.

\section{Introduction}

Poetry is the heritage of national culture. It is a source of knowledge for children about the world, in which they grow, form, develop, brought up. Poems often become for the child the first acquaintance with the sound and expressiveness of speech. The world of emotions are formed in childhood, and fiction, the first books that the child are acquaints with, along with the environment and society determine the development of the sphere of individual feelings. Along with the environment and social conditions on the formation of a sensitive world of children's emotions, poetry has a significant influence on. The children's love for language takes place through fiction, in particular through poetry. Poetry that is devoted to children has not distinguished as an independent genre of literature for a long time. The problem of studying the phenomenon of children's poetry is one of the most comprehensive. Among the scientific works, the study of the children's poetry turns out to be little researched. This focus accounts for the relevance of the study.

The aim of this research is to determine the concept "children's poetry", to identify the main features of the stages of development of English-language children's poetry.

The aim of the work involves solving the following tasks: to find out the specifics parameters of the peculiarities of the children's poetry; to identify the main features of the genesis and the development of the children's poetry; to consider the English-language children's poetry from the beginning of its genesis to nowadays; to observe creativity of English-language children's poets as the representatives of each stage.

The object of the study is the process of genesis and development of the English-language children's poetry. The subject of the study are the peculiarities of children's poetry on each stages of its development.

The following methods of analysis have been used to achieve the purpose and to solve the tasks: descriptive (for the representation of the main 
work material); hypothetical-deductive, which determined the selection of actual material; method of analysis of vocabulary definitions (for revealing features of concept "children's poetry"); analytical-synthetic method (for the distinguishing the main stages of the genesis and the development of the English-language children's poetry and the description of their features).

The scientific novelty of the research is the suggested analysis of the English-language children's poetry from the beginning of its genesis to nowadays.

\section{Definition of children's literature}

Cuddon (2013) defines literature as "a broad term which usually denotes works which belong to the major genres: epic, drama, lyric, novel, short story, ode" [7, p. 404]. Childs and Fowler (2006) says that "in present times literature generally taken to be imaginative compositions, mainly printed but earlier (and still, in some cultures) was oral, whether dramatic, metrical or prose in form. This is a relatively recent usage, having general acceptance in the European languages only from the nineteenth century. Earlier senses have been less restricted: for example, the body of writings in a language, artistic or not; and particularly, the study of such a corpus of written materials" [6, p. 129]. Literature is the art of a word that reflects reality in artistic images [2, p. 396-397].

In the array of literature children's literature is distinguished, the main criterion for such a diversification is the category "reader-child". Townsend (1990) understands literature as the work of the imagination, transmitted through written speech or oral narration, formed as novels, stories, poetry and have a literary nature in accordance with stylistic features. Literature is an enjoyment of the use of art that originates from the raw material of life, the expansion of imagination, deepening of experience, raising awareness $[25$, p. 60]. While the existence of children's literature is entirely depended on ties to a particular reader's audience which is "children" [13, p. 17].

Hunt (1994) interprets children's literature as a term for describing the totality of texts written for children, as well as academic discipline [12, p. 1-12].

For a long time there was the concept of "children's reading", that is, children had the opportunity to read the literature that was intended for adults. There were almost no children's books. Their absence is explained by the fact that "the discovery of a child" occurred in world culture in the 
eighteenth century, which served as an impetus for the formation of children's literature as part of children's culture. The absence of children's books was compensated by works of folk art (folklore), which in all ages finds the way to the heart of the children. At the present stage of the development of society, children's books are an important part of culture.

These processes take place in many countries. In the culture of each country, children's literature has its own history and specifics. However, children's literature in different countries has common features [4, p. 5].

Shavit $(1986 ; 1995)$ affirms "the same historical model is common to all beginnings of children's literatures. The same stages of development reappear in all children's literatures, regardless of when and where they began to develop. Moreover, the same cultural factors and institutions are involved in their creation. The view was shared that in the process of children's education, they needed books, which must differ from adult books principally through their fundamental attachment to the educational system itself. Thus, it was through the framework of the educational system that a canonized children's system began to develop" [20, p. 133-134; 21, p. 27-38]. Ray (1996) confirms that the development of children's literature is linked to social, educational and economic factors. The complexity of its development illustrates the importance of cultural and political influences [17, p. 654; p. 661]. Zipes (2002) observes "the institution of children's literature as it presently exists is mammoth and very complex, and it has undergone vast changes in the last thirty years. The institution of children's literature did not come into play in full force until the eighteenth century" [27, p. 45].

It is logical to find out the necessity to identify children's literature with its intentions and its audience. O' Sullivan (2005) points out 'the key difference between children's and adult literature lies in the fact that the former is written or adapted specifically for children by adults [16, p. 13]. Stephens (1992) writes “children's literature belongs to the cultural practices which exist for the purpose of socializing their target audience. It is a body of literature into which the dominant social, cultural and educational norms are inscribed" [22, p. 8]. Gavriilidis (2011) observes "definition of children's literature is quite difficult because leads to historical, cultural, educational and economical facts and on the other hand, leads to its audience, the relationship between author and audience, and the idea of child that the author is addressing [10, p. 23-24]. 
Hunt (1991) writes "If we define children's literature according to her purposes, can quite reasonably be defined as books read by, especially suitable for, or especially satisfying for, members of the group currently defined as children definition [11, p. 61-62]. This scholar points out "On the whole, then, that a particular text was written expressly for children who are recognizably children must be part of the definition [11, p.23]. Children's books are generally shorter; they tend to favour an active rather than a passive treatment, with dialogue and incident rather than description and introspection; the story develops within a clear-cut moral schematism. Children's books tend to be optimistic rather than depressive; language is child-oriented; plots are of a distinctive order; and one could go on endlessly talking of magic, and fantasy, and simplicity, and adventure [11, p.23].

In our work we use the notion "children's literature" - works of fiction that are directly addressed to children and specially created for them.

\section{Folklore as the tendency to originate of children's poetry}

Prose genres, drama, children's poetry, lyric and epic genres are distinguished among the genres of children's literature. Children's poetry as a genre of children's literature has its artistic peculiarities [1, p. 21]. The question of the specifics of children's poetry remains open, because this phenomenon does not always recognize the right to independent existence, because children's literature appeared much later than literature in general. But thematic, stylistic and functional differences between the works addressed to children and works intended for the adult reader are quite noticeable, in particular, these differences are manifested the most brightly, depending on the age of the younger reader to whom the works are addressed.

As noted above in the culture of each country, children's literature has its own history and specifics. However, children's literature of different countries also has common features [4, p. 5]. In addition, consequently, children's poetry of different countries corresponds to these features as one of the genres of children's literature: it has its own history of formation (stages / periods of development), specific features, classification according to various parameters, general features as one of the types of art.

It has been developed historically; children's poetry existed in oral forms, while being used for learning and entertaining. It is oral folk art, which can be defined as a tendency for the preparatory process of formation of children's literature with its genre diversity in a separate direction in the cultural-historical process of the formation of literature in general. 
Hand-made books existed until the development of the typographic industry, but they were only available to a small number of children of wealthy families. However, most children absorbed rhymed works from oral literature (folklore) that they have heard. Poetic forms of English oral folk art for children "include lullabies, work songs, ballads, nursery rhymes" [8, p. 9]. Children's folklore, characterized by a wealth of genres and forms of significant artistic value and ethno-pedagogical significance, can be considered not only as an impulse for the development of children's literature, not only as a basis for the emergence of children's poetry in particular, but as an organic component of children's literature in general.

Based on historical sources, it is known that poetry for children originally existed orally, used for learning and entertaining, and had the form appropriate for a certain childhood and for children's literature in general. Before the emergence of typographic affairs, books that were formatted in writing were only available to children of wealthy families. Most children, having no such books, have absorbed the works of oral folk art that they have heard. The poetic forms of such literary works include lullabies, songs, cute and fun, amusements and the like.

\section{Printing is the impulse for the development of children's literature}

The emergence of printing becomes the key point from which the indication of the formation of fiction begins. The typographic affair is the beginning of the genesis of children's literature.

Oral folk art and literature in the whole of the XI-VIII centuries can be regarded as a tendency that has prepared the formation of children's literature, in particular children's poetry, into an independent branch of the historical and literary process.

Until the nineteenth century, literature for children was not isolated as a separate branch of art, since it was a part of the "adult" literature. In the ancient and medieval world, the history of literature did not record certain works that were devoted to children. Although in some philosophical writings there are opinions concerning the importance of literature in the process of upbringing a child. The emergence of schools and libraries (selected biblical tales, the lives of saints and legendary people, Psalter, etc.) are considered as the impetus for the moral, educational, cognitive and didactic orientation of literature. The Renaissance has examples of literature for young children. Thus, the Italian poet G. Pontano makes up lullaby songs, another Italian - Faern composes "Interesting collection" (fables for children). 
Thus, the emergence of printing is the impulse for the development and positioning of children's literature in different countries of the world.

Poetry comes into children's life orally. Even nowadays, in the world, oversaturated with media, nursery rhymes and word play acquaint children with the language and culture of their native country. As in other cultures, English-language children's poetry historically reaches the traditions of oral folk art, that is existed initially only in oral form.

From the birth up to now, poetry for children is formed by the generations of children and the literature of childhood in general. In other words, each new generation of children led to the emergence of new poetic texts for the young reader, which corresponded to the historical, cultural, social and other conditions of the development of a certain country. At the same time, children's poetry at various stages of its development and becoming is a part of the literature of childhood, and therefore it corresponds to the age features and the level of the development of young readers, the formation of their emotional sphere, etc. These features cause the certain linguistic peculiarities of children's poetry, which are manifested in the individual peculiarities of poetic speech of different authors.

Periods of genesis and development of English-language children's literature in most cases are determined in accordance with the stages of the history of literature in general. Hunt (1994) notes that children's literature should be considered outside the literary hierarchy, that is, as its own system, which has a relationship with literature and culture as a whole $[12$, p. 7]. Children's literature reaches its roots not only in literary but also in the cultural heritage of a specific society $[12, \mathrm{p} .1]$. Children's literature can be regarded as a certain cultural and ideological construct [5, p. 19], because children in reading maintain a "living sense of nationality" and support "a sense of humanity" [14, p. 146].

English-language literature, like all others, existed in the form of handmade books until the development of typographic production. For most children, the main sources of education and entertainment were poetic forms of oral folk art. In the fifteenth century. The publication of literary texts for children for the purpose of education and upbringing began. Therefore, "Courtesy books" payed attention to the rules of behaviour, often referring to rhyme, which helped with the process of memorization. For example, "Symon's Lesson of Wisdom for All Manner Children," "The Babees'Book" did not aim to get familiar with the art of the word, since they were aimed 
only to the instruction of the rules of behaviour: "Child, over men's houses no stones fling / Nor at glass windows no stones sling... / Child, keep thy book, cap and gloves / And all things that thee behoves, / And but thou do, thou shalt fare worse / And thereto be beat on the bare erse" [26, p. 4].

In 1646, John Cotton wrote the first book for children "Milk for Babes, Drawn out of the Breasts of Both Testaments, Chiefly for the Spirituall Nourishment of Boston Babes in either England, but may be of like Use for any Children", which was published in the "New World", and contained in its content certain concepts of Puritan theology in verse: Who is the Maker of all things? / The Almighty God who reigns on high. / He form'd the earth, He spread the sky [24, p. 45].

The book "A Book for Boys and Girls" (1686), written in verse by John Bunyan, and later published as Divine Emblems (1724), was not very popular, since the poetry was rather plump and not readable by modern readers $[8$, p. 10].

In 1680, the book "The New England Primer" was published for the first time, containing a large number of pictures and poems. The poems aimed at teaching reading and upbringing of moral principles. The book has become the first textbook for children in American colonies and is well-known for its rhymes and xylographies / woodcuts (one rhyme for every letter of the alphabet). In the next millennium, this book has been re-printed more than once, and some of the rhymes from it are still known: "In Adams fall / We sinned all." [8, p. 10].

By the middle of the XVIII century most poems for children were difficult to perceive (fables with morals and hymns), sometimes even with dramatic sounds and didactic orientation [12, p. 188].

\section{Education through entertainment}

The collection of folk tales "Tales of Mother Goose" was published in English in 1729 by R. Samber in the form of a small pamphlet. Although all fairy tales in it were written in a prose form, but the morals to them were written in rhymed form.

Dr. Isaac Watts considers rhyme to be a useful tool in the didactic aspect, in the preface to his "Divine and Moral Songs for Children" (1715), the author focuses on the value benefits of poetry in teaching children, noting that there is something funny in the rhyme and meter, which encourages children to comprehend what they perceive; which helps to keep in memory 
and quickly remind what they have learned. Both sounds and number of syllables are an extremely powerful tool for children's memory [25, p. 104]. Dr. Isaac Watts was successful enough to use rhymes than his predecessors, as evidenced by the repeated reprint of his "Divine and Moral Songs for Children" over the next several millennia in America and England. Some of his poems are contained in modern poetry anthologies for children. The poetry of the author softens the puritanical views.

Along with poetic texts Dr. Isaac Watts, the "Mother Goose" rhymes, which do not belong to any of the well-known authors, were rather popular, and the date of their first edition is not exactly set. Rhymes "Mother Goose" still provides children with the first ideas of poetic elements, such as alliteration, onomatopoeia, rhyme and meter. These rhymes have "sing-song quality and variety of topics and types - alphabet, proverbs, stories, songs, nonsense, and tongue twisters, to name a few - the rhymes range from nonsensical to instructional." [8, p. 11]. Despite the fact that they are often ignored as literary heritage, they are popular due to the transition from oral to written literature.

At the same time, a significant contribution to the development of children's poetry is the publication of John Newbery's book "A Little Pretty Pocket-Book" (1744), which included rhyming games, morals, alphabet poems and other types of poetry. This book was important both in the didactic and entertainment aspects. The author's contribution to the development of children's literature is a part of the movement to expand the social, cultural, moral, spiritual and literary ideas of the middle class of England during the 1800s [19, p.1-9]. By the way, one of the facts proving the value of the John Newbery's contribution to the development and establishment of children's poetry and children's literature in general as an independent genre of artistic art, is the prestigious award in the children's literature of the United States - The Newbery Medal.

Moral fairy tales in verse gradually evolve into extravagant cautionary verses. Popular are careless poems about animals. In poetry, there are gradually emerging themes of expression of tender feelings between parents and children, which are often formed as lullabies [12, p. 188].

William Blake in his "Songs of Innocence" (1789) expands the concept of combining moral education with an entertaining element of poetry for children. So, for example, the author completes the first verse of his collection in the following lines: "And I made a rural pen, / And I stain'd the water clear / And I wrote my happy songs / Ev'ry child may joy to hear". 
He also made illustrations for each verse in the form of decorative ornaments. His poems were subsequently included in the anthologies of poetry for children's reading.

At this time, the poetry of sisters Ann and Jane Taylor gains popularity. The collection of their poems "Original Poems for Infant Minds" (1804) contained one of the most sentimental verses of the time "My Mother". The book "Original Poems for Infant Minds" has been translated into some other languages. One of the most popular poems to these days is "Twinkle, Twinkle, Little Star", authored by Jane Taylor. Sisters also wrote "Rhymes for the Nursery" (1806) and "Hymns for Infant Minds" (1808). Ann and Jane Taylor's poetic texts follow the literary tradition of moral education through rhymed texts, initiated by Dr. Isaac Watts, enliven poetic speech with the presence of energetic stories in the form of a story.

Thus, English-language children's poetry develops from the rhyming moral norms in accordance with the existing theological dogmas of that time to a genre that captures multitudinous stories in rhymed form and delights the young reader with the sound design and rhythm of speech.

In 1807, an illustrated book by William Roscoe "The Butterfly's Ball" was published in England. The text of the poem is integrated with the illustrations. On one page of the book, there was one verse poem and a charming illustration. Although the verse does not differ in literary value, it is interesting because it is deprived of the rules of morality, which until then were conditioned by the church canons. This fact allows us to suggest the idea of the further development of poetic representation and thinking, free from church influence.

In 1823, the work "A Visit from St. Nicholas" was published. It considered being the creative work of Clement $\mathrm{C}$. Moore, although some researchers attribute this work to Major Henry Livingston, Jr. A narrative-poem with rapidly changing storylines, humour, and, again, the lack of church and moral teachings. This work has been repeatedly reprinted and still read. In 1842, Robert Browning's novel in the form of poem "The Pied Piper of Hamlin" is published, although it contains morality, but it is interwoven with elements of fantasy.

On the literary field, there are poets-humourists who make poems-nonsense. These poems occupy a significant part of children's poetry. The most common forms are limericks, songs, etc., which are rhymed in a metrical regular verse [12, p. 188]. 


\section{Nonsense in children's poetry}

In 1846, the world saw the book of Edward Lear "Book of Nonsense" a collection of limericks-nonsense with the author's illustrations. This book has begun a new stage in the development of English-language children's poetry. The author's creative works also includes nonsense stories in rhymes, some of which are the part of modern collections of English-language children's poems ("The Jumblies", "The Owl and the Pussy-Cat" from the book "Nonsense Songs" (1870)). Edward Lear's creativity begins a new stage in the history of becoming a fantasy as a literary genre.

English-language children's literature, as well as poetry for children of this period, is marked by the coverage of unusual artistic inventions, stories-nonsense in verse, fantasy. All these elements, having specific linguistic and stylistic features of poetic speech, reached the process of the formation of children's poetry and had bright examples of development. Therefore, in 1862, the poet and illustrator Christina Georgina Rossetti creates an original fairy tale in the poetic form "Goblin Market". The poetry of the author is published in the anthologies of children's poetry.

In 1878, a collection of poems "Under the Window" by Kate Greenaway appears with own illustrations to them. The book of the poet was published not only in the UK, but also in the United States and had a great success.

At the same time, English-language children's poetry is supplemented with poetry by Robert Louis Stevenson. In 1885 a collection of poems "A Child's Garden of Verses" was published. The poems from this collection are contained in the anthologies of children's poetry, and the collection itself is repeatedly reprinted in the format of an illustrated book.

At the end of the nineteenth century a collection of poems by Eugene Field "Lullaby Land" (1897) appeared. Now only a few poems are found in children's anthologies ("Wynken, Blynken and Nod"). "Little Orphan Annie" by James Whitcomb Riley is one of the most famous poems. He was recognized as an American poet who wrote for children. The features of his poetic speech are characterized by the skillful ability to use the vocabulary of spoken language and dialectal vocabulary, while representing the possibility of interesting and funny using of non-standard vocabulary in the English literary language: "The gobble-uns'll git you / Ef you / Don't / Watch / Out!' [18, p. 1]. These skills are manifested both in the linguistic design of poetic texts, and in the graphic. 


\section{Humour of children's poetry in the twentieth century}

In the twentieth century the English-language poetry for children is gaining momentum, which leads to an increase in the range of poets who create for children, and as a consequence the development of new directions using a wide range of linguistic and stylistic means of expressing the peculiarities in the children's poetic texts.

So, the beginner in the format of one poem with illustrations in one book becomes the English author Leslie Brooke, who wrote and illustrated “Johnny Crow's Garden" (1903). In the USA, Laura Richards writes poetry for the children's magazine "St. Nicholas" (Tirra Lirra (1932)). At the same time, English poets Walter de la Mare and Eleanor Farjeon write poetry and prose for both adults and children ("Peacock Pie" (1917), "Rhymes and Verses" (1947) - favourite collections of poetry by Walter de la Mare; "Eleanor Farjeon's Poems for Children" (1951); "The Children's Bells" (1960); "Kings and Queens" (1983) - collections of poetry by Eleanor Farjeon. The poetry of these poets are still published in anthologies of children's poetry.

In the United States artists such as Robert Frost and Carl Sandburg are working. Several photoversion of illustrated collections by Robert Frost still exist, and his poetry continues to be anthologized. Verses by Carl Sandburg from "Early Moon" (1930) i 'Wind Song” (1960) are included in modern collections of children's poems.

Some of the most popular poets of that time, who wrote for children, include A.A. Milne. His collections focused on the child include "When We Were Very Young" (1924) and "Now We Are Six" (1927), which remain popular today. Elizabeth Coatsworth wrote several collections of poems for children "Summer Green" (1948), "Poems" (1957), "The Sparrow Bush" (1966), "Down Half the World" (1968).

In the USA one of the most popular poets of that time who worked for children was Theodore Seuss Geisel / Dr. Seuss. Most of his works ("The Cat in the Hat", "Green Eggs and Ham", "One Fish, Two Fish, Red Fish, Blue Fish" and others) are rhymed stories. The author adheres to the traditions of nonsense with the elements of early poetry of morality (church canons). All these peculiarities are combined in poetic text with unique characters and author's illustrations. His collection "The Cat in the Hat" (1957) is a contribution to the development of the genre, which has gradually become popular. This genre includes poetry for kids who begin to 
read. Using lexical units that are common to a child, a simple rhyme, in the meantime the author tries to create an exciting impression: "The sun did not shine. I It was too wet to play. / So we sat in the house / all that cold, cold, wet day." [9].

Poetry for children was written by a large number of poets including Harry Behn, Gwendolyn Brooks, Aileen Fisher, Langston Hughes, David McCord, Eve Miriam, Theodore Roethke, May Swenson. May Swenson expands the limits of the traditions of poetry, creating a free verse that forms puzzles and riddles. Eve Miriam also adheres to such traditions, but also adds a certain range of themes to children's poetry. At this time, the tendency towards approaching poetic texts in the form to the prose is traced. Children's literature reaches active development.

Poetic forms in children's poetry continue to be replenished with new ones, traditional ones are improved, the boundaries of the thematic circle expanding over time. It is worth of attention the poetry of many contemporary authors: Allan Ahlberg, Hilaire Belloc, Valerie Bloom, John Ciardi; Beatrice Schenk De Regniers, Paul Fleischman, Roy Gerrard, Nikki Giovanni, Karen Hesse, Mary Ann Hoberman, Lee Bennett Hopkins, Ted Hughes, Randall Jarrell, Dennis Lee, Myra Cohn Livingston, Brian Moses, Ogden Nash, Charlotte Pomerantz, William Jay Smith, Jean Sprackland, Roger Stevens, Gez Walsh, Nancy Willard, Jane Yolen and others.

Some of the modern poets have received awards for their contribution to the development of children's literature in general, and children's poetry in particular.

Children's poetry undergoes radical changes since the 1970s, as this poetry becomes closer to the "real world.» Humour remains widespread in children's poetry, although serious topics are not neglected [12, p. 188].

At the end of the twentieth century, children's poetry is completed with such names as Sheldon Alan 'Shel' Silverstein and Jack Prelutsky. Poetry by Sheldon Alan 'Shel' Silverstein "Where the Sidewalk Ends" (1974) and "A Light in the Attic" (1981) are distinguished by their easiness of perception of poetic texts. The author uses humor in combination with elements of nonsense, which have been initiated by Edward Lear and supplemented by Theodore Seuss Geisel / Dr. Seuss. By the way, Sheldon Alan 'Shel' Silverstein creates his own illustrations to his books. Jack Prelutsky's most popular collections are "Rolling Harvey Down the Hill" 
(1980), "Hooray for Diffendoofer Day!" and others. All collections of the poet are illustrated.

One of most popular and beloved Britain children's poets is Brian Moses. In his poetry, traditions of nonsense are combined with the usual everyday images that children occur in life, thus a surrealism appears.

Allan Ahlberg is the author of many children's books, including the collection of poems "Please Mrs Butler" (1983), "Heard it in the Playground" (1989). The book illustrator was his wife Janet Ahlberg. This couple differed by the productive work in the sphere of children's literature, since they created a large number of works devoted to children of all ages and were repeatedly recognized as the best in the field of their activities (Allan Ahlberg as a children's writer, and Janet Ahlberg as illustrator for children's books).

In 1997, Gez Walsh's poetic work for children, included in the collection "The Spot on My Bum: The Horrible Poems for Horrible Children", flashes brightly. The author devoted his poems to his son, but in a rather short time, the collection became an iconic. Gez Walsh, thinking of writing poetic texts, sought to create poems readable to his son, and which would stimulate reading. The main artistic means in the poetry of the author is humour, which serves as a means of encouraging reading. It turned out that Gez Walsh's poetry is one of the effective methods of encouraging reading.

\section{Visual images as a part of children's poetry}

The development of children's poetry is accompanied by the improvement of its visual design. The process of illustrating poetry depends on the type of poem. At the end of the twentieth century, technical progress distinguishes illustrations of poems for children from their counterparts in previous centuries. Regarding the design of illustrations for children's books, there are controversies among researchers, as there is a large number of questions: if the illustration is not well thought out and executed not qualitatively, it can deform the children's imagination; such illustrations can also alienate children from creating their own comprehension; too many illustrations may stop the process of creating their own images in children's mind; it is very important to be careful in the process of creating illustrations for babies, as a child may encounter some concepts for the first time. Other issues are also highlighted: the format of illustration of a book can lead to a rupture of poetry's stanzas, which can change the rhythm and tone that the author has 
conceived. When making illustrations to the book of poems, it is necessary to take into account all the intentions of the author, in order to avoid distorting the cadence of the poet. Poetry of the authors who wrote in previous centuries needs particular attention in this. The visual representation is best suited to poetry with storylines [14]. Therefore, in order to prevent the distortion of the poetic text of the book, there should be visual interpretations of the poetry, sometimes in relation to the text they should be less.

In connection with the above, we consider it is necessary to pay attention to the fact that almost all collections of children's poems contain illustrations that also have their development trends associated with both the development of art and the development of literature, which again depend on cultural and historical conditions of the development of the society of a particular country. Speaking about the children's book, in particular the collection of children's poetry, worthy of attention is the fact that an important and inalienable part of it is an illustration. The children's book is a syncretic unity of a picture and text [1, p. 30].

The child does not get the first knowledge about the world in a verbal way, but in an audio-visual way, so it is difficult to learn writing and reading without a picture. As the reader grows up, the reader begins to acquire only an auxiliary role, and the child learns to interact mentally with literary artistic images, and not with pictures [3, p. 76].

According to the age peculiarities the child does not read yet, but only begins to learn to read, in books for children of preschool age, the illustration dominates the text, while in the artistic design preference is given to bright colours, as well as to the large font of letters, because a child perceives them as a picture, remembers and tries to find them. In the editorial preparation of publications for children, it is stated that the presence of colour in illustrations and book design is one of the main requirements for preschool books. Coloured drawings have wider emotional, cognitive and decorative possibilities. Bright colours, clear contours of drawings, and a large font are what editors take into account when preparing the publications for preschool children [3, p. 77]. These requirements remain relevant to illustrated editions for junior schoolchildren. Still there are such qualities as anthropomorphism and animism of child psychology. However, the text begins to dominate the pattern, the font is reduced, the volume of text increases, and the illustrations are not saturated with bright colours. The realism of the image comes to the foreground, the aesthetic function of the 
illustration is enhanced [3, p. 78]. It becomes clear that even the design of illustrations to children's poems, as dependent on the psychophysiological features of the recipient-children, that is, adjusted by them, and aimed at a small searcher of the world, that is, designed for the child.

The pictures in books not only serve as a visual accompaniment to the text, they also involve children in art, in the world of beauty. Some authors are illustrators of their own poems (Dr. Seuss, Sheldon Silverstein, and Philip Dey Eastman). Modern editions of poetry intended for children are distinguished by bright fascinating illustrations that help to perceive the text through the visual channel, and thus enhance the impression of what children hear or read. It revives the work of the children's imagination, promotes the creative development of children.

At the end of the twentieth century and the beginning of the twenty-first century, the anthologies of children's poetry are published actively (The Random House Book of Poetry for Children (1983), Read-Aloud Rhymes for the Very Young (1986), and Sing a Song of Popcorn (1988), Poems for Big Kids : Rhyming poetry for children ages 8 - 13 (2008), Ambleside Online Year 1 Poetry Anthology (2011), Children's Collection of 176 Poems : Year 1 Anthology (2014)).

Modern poetry for children has informal and unstructured forms, although the forms of the past are not rejected or neglected.

At the stage of modern development of children's poetry, the recognition of children as small artists of words takes place [12, p. 188-189]. At the end of the twentieth century, there is also a revival of interest not only in poems written for children, but also in poems written by children. It is witnessed by the organization of events such as Poetry in Motion, Poems on the Underground, and the National Poetry Month, which encourage children to create their own poems.

\section{New technologies and children's poetry}

XXI century brings to our lives new social changes and the constant development of electronic technologies, which are improved every day. Rapid technical progress makes it possible to create new resources for familiarizing children with the world of poetry. Therefore, Representative Poetry Online (http://rpo.library.utoronto.ca/display/index.cfm), Children's Literature (http://www.famousliteraryworks.com) represent English-language children's poetry database online. Similar information is available on 
Children's Poetry and Poetry Lessons (http://www2.nkfust.edu.tw) - a large number of links to sites that extend the understanding of the concept "children's poetry". The special sites are created to encourage children to rhyme poetic texts on their own, to play with the rhyme, to supplement knowledge in the field of poetry, to interact with other children. For example, the following sites have been created specifically for children: Giggle Poetry (http://www.gigglepoetry.com), which hosts works by Bruce Lansky and other children's poets associated with the Meadowbrook Press; Poetry4Kids (http://www.poetry4kids.com), a site for a contemporary American children's poet, which houses not only his poetry, but also the poetry playground section; Poetry Zone (http://poetryzone.co.uk), created by the English poet Roger Stevens; Poetry Writing With (http://teacher.scholastic.com/writewit/ poetry/jack_home.htm) is website with Jack Prelutsky's poems and other children's poets, published by Scholastic. For English teachers, there are websites that offer various types of work to teach children to create poetic texts (Boston Teachnet (http://www.technet.org), Education World (http:// www.educationworld.com), Web English Teacher (http://www.webenglishteacher.com), Poets House (http://www.poetshouse.org)). There are recorded audiobooks for children's poetry (PoetryFoundation.org (http:// www.poetryfoundation.org), Poets.org (http://www.poets.org), Children's Poetry Archive (http://www.poetryarchive.org)). Various author's webpages also offer self-titled audio tracks, usually in musical accompaniment and with illustrations (http://www.poetry4kids.com, http://www.shelsilverstein.com, and others). PBS Poetry Site (activities. http://www.pbs.org) contains poetry, lesson plans for teaching poetry, games and various cognitive activities related to rhyming.

\section{Conclusions}

Based on the above, it is worth to say that English children's poetry continues to develop, thrive, refresh, refine, expand its boundaries in all its aspects (content, forms, subjects, linguistic peculiarities, etc.). As long as children learn, they must be submerged in the poetic art of the word, which not only teaches, but also promotes the development of the conception, and therefore, their form and content, rhyme and rhythm will interest children, even in the modern world of the latest technologies.

Oral folk art can be defined as a tendency for the preparatory process of formation of children's literature. The emergence of printing is the 
beginning of the genesis of children's poetry. A significant contribution to the development of children's poetry is the publication of John Newbery's book "A Little Pretty Pocket-Book" (1744) which is important both in the didactic and entertainment aspects. In 1846, the world saw the book of Edward Lear "Book of Nonsense". This book has begun a new stage in the development of English-language children's poetry. Humour is the main feature of children's poetry in the twentieth century. The development of children's poetry is accompanied by the improvement of its visual design. XXI century brings to our lives new social changes and the constant development of electronic technologies. Rapid technical progress makes it possible to create new resources for familiarizing children with the world of poetry.

The creative imagination of both the poet and the child widens the boundaries of poetry, Since poetry texts serve not only as a means of learning and upbringing but also appear in a large-scale dimension as a source of searching of the world, the replenishment of knowledge, awareness of moral, ethical and aesthetic norms, the development of impression, thinking and memory, emotional formation of personality, because it always excites.

\section{References:}

1. Arzamastseva, I.N., Nikolaeva, S.A. (2000). Detskaya literatura [Children's Literature]: ych. dlya stud. vyissh. i sred. ped. uch. zavedeniy. Moskva: Vyisshaya shkola. (in Russian)

2. Hromiak, R.T., Kovaliv, Yu.I., Teremko, V.I.(Red.). (2007). Literaturoznavchyi slovnyk-dovidnyk [Literary dictionary-reference book.]. Kyiv: "Akademiia".

3. Zyilevich, D.P. (2012). Redaktorskaya podgotovka izdaniy dlya detey [Editorial preparation of publications for children]: ucheb. posobie dlya studentov spetsialnosti "Izdatelskoe delo". Minsk: BGTU.

4. Putilova, E.O., Denisova, A.V., Dneprova, I.L. i dr. (2010). Detskaya literatura [Children's Literature]: uch. dlya stud. sred. prof. ucheb. zavedeniy. (3-e izd., ster.). Moskva: "Akademiya".

5. Bimberg, C. (2000). The Potential Contribution of Children's Literature to multilingualism and Multiculturalism. Per Linguam. (V. 16, No. 1, pp. 18-31).

6. Childs, P., \& Fowler, R. (Eds.). (2006). The Routledge dictionary of literary terms. New York: Routledge. Taylor \& Francis Group.

7. Cuddon, J.A. (2013). A dictionary of literary terms and literary theory. (5th ed.). Oxford: Wiley-Blackwell.

8. Dixon, A. (2008). Poetry and Children. In N.H. McAlister, \& Z. McAlister, Z. (Eds.). Poems for Big Kids (9-18). Retrieved from www.durham.net/ neilmac/ travelerstales.htm

8. Dr. Seuss. (1985). The Cat in the Hat. New York : Random House. 
9. Gavriilidis, S. (2011). Children's Literature Terms. Glossary DLV. P.IN.O.K.I.O. Lifelong Learning Programme. Comenius Multilateral Project. Retrieved from http://panorama.intercultural-europe.org/_files/20111221-DLV16_1_ Glossary.pdf

10. Hunt, P. (Ed.). (1991). Understanding Children's Literature. London and New York: Routledge.

11. Hunt, P. (1994). An introduction to children's literature. Oxford and New York: OUP.

12. Lesnik-Oberstein, K.B. (1996). Defining Children's Literature and Childhood. In P. Hunt (Ed.). (1996). International Companion Encyclopedia of Children's Literature (pp.17-31). London: Routledge.

12. MacDonald, E. K. (1990). The illustrated poem: An uneasy alliance. School Library Journal, 36(7), 28-29.

13. O'Sullivan, E. (2004). Internationalism, the Universal Child and the World of Children's Literature. P. Hunt (Ed.). International Companion Encyclopedia of Children's Literature (pp.13-25). London and New York: Routledge.

14. O'Sullivan, E. (2005). Comparative Children's Literature. London and New York: Routledge.

15. Ray, S. (1996). The World of Children's Literature: An Introduction. In P. Hunt, (Ed.). International Companion, Encyclopedia of Children's Literature (pp. 653-992). London and New York: Routledge.

16. Riley, J.W. (2011). Little Orphan Annie, and other Poems. (3rd ed.). New York: Dover Publications Inc.

17. Ruwe Palgrave, D. (2014). British Children's Poetry in the Romantic Era: Verse, Riddle, and Rhyme (Children's Verse Between 1780 and 1835). London: Macmillan.

18. Shavit, Z. (1986). Poetics of Children's Literature. Athens and London: University of Georgia Press.

19. Shavit, Z. (1995). The Historical Model of the Development of Children's Literature. In M. Nikolajeva, (Ed.). Aspects and Issues in the History of Children's Literature (pp. 27-38). Westport-Connecticut-London: Greenwood Press.

20. Stephens, J. (1992). Language and Ideology in Children's Fiction. London and New York: Longman.

21. Styles, M. (1996). Poetry for Children. In P. Hunt (Ed.), International Companion, Encyclopedia of Children's Literature (pp. 187-202). London and New York: Routledge.

22. Sutherland, Z. (1997). Children and Books (9th ed.). New York: Addison Wesley Longman.

23. Townsend, J.R. (1990). Standards of Criticism for Children's Literature. In P. Hunt, (Ed). Children's Literature: The Development of Criticism (pp. 57-71). London: Routledge.

24. Townsend, J.R. (1992). Written for Children: An outline of English-language children's literature. New York: HarperCollins.

25. Zipes, J.D. (2002). Sticks and Stones: the Troublesome Success of Children's Literature from Slovenly Peter to Harry Poter. New York and London: Routledge. 